Висновки. 3 огляду на вищевикладене й аналіз сучасного рівня розвитку суспільства, стає очевидним, що інсрормаційна безпека не може сприйматися суто як складник лише національної безпеки, оскільки вона $\epsilon$ глобальною проблемою й у глобальному світі може характеризуватися як складник цілісної кооперативної безпеки.

У сучасних умовах забезпечення інформаційної безпеки для України стоїть на одному рівні із захистом суверенітету й територіальної цілісності. Найбільшою загрозою інфрормаційної ссрери $€$ негативний інформаційно-психологічний вплив держав-супротивників на свідомість громадян і світову спільноту через проведення інформаційних акцій, спеціальних інфрормаційних операцій.

\section{ЛІТЕРАТУРА}

1. Жарков Я.М., Бєсєдіна Л.М. Напрямки зовнішнього інсрормаційно-психологічного впливу на Україну. Збірник наукових праць Військового інституту Київського національного університету ім. Т. Шевченка. Київ, 2009. № 19. URL: <http//www.nbuv.gov.ua/ portal/natural/znpviknu/2009-19/vip19-21.pdf>.

2. Капица С.П., Курдюмов С.П., Малинецкий Г.Г. Синергетика и прогнозы будущего. 3-е изд. Москва: Едиториал, 2003. 288 с.

3. Ковтун С.В. Інформаційна безпека: підручник. Харків. Вид. ХНЕУ, 2009. 368 с.

4. Про основні засади розвитку інсоормаційного суспільства в Україні: Закон України від 09.01.2007.
Відомості Верховної Ради України. 23.03.2007. № 12. $511 \mathrm{C}$.

5. Ситник Г.П., Олуйко В.М., Вавринчук М.П. Національна безпека України: навчальний посібник / за заг. ред. Г.П. Ситника Г.П. Київ, 2007. 225 с.

6. Сунь-цзи. Искусство войны. URL: <http:// royallib.com/book/suntszi/iskusstvo_voyni.html>.

\section{REFERENCES}

1. Zharkov J., Besedina L. Napriamki zovnoshniogo informatsiino-psohologichnogo vplivu na Ukrainu. Zbirnik naukovih prats Viyskovogo institutu Kyyivskyj nacionalnyj un-t im. Tarasa Shevchenka. 2009. № 19. URL: http// www.nbuv.gov.ua/portal/natural/znpviknu/2009-19/ vip19-21.pdf

2. Kapitsa S., Kurdiumov S., Malinetskiy G. Sinergetika I prognizy budushego. M.: Editorial, 2003. $288 \mathrm{~s}$.

3. Kovtun S. Informatsiina bezpeka: pidruchnik. Kharkiv: Vid HNEU, 2009. $368 \mathrm{~s}$.

4. Pro osnovni zasadi rozvitku informatsiinogo suspilstva v Ukraini: Zakon Ukrainu vid 09.01.2007. Vidimosti Verhovnoi Rady Ukrainu. 23.03.2007. № 12. $511 \mathrm{~s}$.

5. Sytnik G., Oluiko V., Vavrinchuk M. Natsionalna bezpeka Ukraini: navchalniy posibnuk / za zag. red. G. Sitnika. Kyiv, 2007. 255 s.

6. Sun-tzi. Iskustvo voiny. URL: http://royallib.com/ book/suntszi/iskusstvo voyni.html.

\title{
Transformation of information security notion due to globalization
}

Ryzhuk Oleksandr Mykolaiovych

Applicant at the Department of Social and Political Sciences,

Global Studies and Social

Communications

Open International University of Human

Development "Ukraine"

Lvivska Str., 23, Kyiv, Ukraine
In this article is researched the notion of "information security" which the integral part of general formation provision problem for a person, state and society.

Given are the leading researches approaches both Ukrainian and foreign to the information security. Mentioned are their definitions and view of point on this notion.

Shown is the transition of the information security notion from national to global level due to globalization.

Key words: security, information, information security, globalization. 


\section{Феномен націоналізму: історія становлення, типологія та сутнісні характеристики}

УДК 321(477.8)

DOI https://doi.org/

10.24195/2414-9616-2018-1-23-28

Стародуб Тарас Петрович аспірант кафредри політології та міжнародних відносин Національного університету «Львівська політехніка» вул. Степана Бандери, 12, Львів, Україна

\begin{abstract}
Метою дослідження є вироблення власного узагальненого погляду на націоналізм на основі аналізу праць ідеологів і дослідників цього френомена.

У статті використано такі наукові методи дослідження: метод історизму, порівняльний та аналітичний методи, структурно-системний аналіз.

здійснено комплексний аналіз історії становлення націоналізму, типології, складників цього поняття, з'ясовано погляд на націоналізм у різні історичні епохи.

Досліджено, що націоналізм за своєю сутністю є складним, контроверсійним і водночас багатогранним явищем, яке може мати ознаки як демократичні, так й авторитарні, може бути спрямоване в майбутнє чи орієнтоване в минуле. Проаналізовано багато класифрікаційних і типологізаційних теорій націоналізму; але показовою, на думку автора статmі, є типологія націоналізму єврейського дослідника Ганса Кона, який, аналізуючи націоналізм у процесі історичного розвитку, поділяє його на східний і західний.

З'ясовано, що для націоналізму нація - найвища цінність, єдина обов'язкова інстанція, що надає йому сенсу й виправдовує його. Установлено, що головний принцип націоналізму - творення та зміцнення національної держави, носієм суверенітету в якій є нація.

Багато науковців виходять із того, що націоналізм - це рух, метою якого є пошук тісного зв'язку між державою й нацією, без якого націоналізм втрачає своє суспільне та політичне значення. Без такого поєднання націоналізм міг би зацікавити хіба що фольклористів. Націоналізм вимагає національної держави, бо саме чей процес (творення національної держави) зміцнює націоналізм

Отже, існує безперервна взаємозалежність і взаємодія між націоналізмом і національною державою. Очевидним є той фракт, що саме розвиток і поширення націоналізму сприяло виникненню держав. Багато дослідників нерозривно поєднують поняття «національна держава» $з$ поняттями «нація» та «націоналізм». Націоналізм твердить, що нація та держава існують одне для одного, більше того, одне без одного не можуть існувати, а відсутність одного з них спричиняє трагедію для іншого.

Ключові слова: націоналізм, нація, національна держава, історіографія націоналізму, типи націоналізму, теорії націоналізму.
\end{abstract}

Вступ. Питанням націоналізму присвячена величезна кількість джерел, досліджень, наукових праць провідних європейських мислителів і вчених-дослідників XIX-XXI ст. Націоналізм загалом - це ідеологія й напрям політичної думки, основним принципом якого $€$ твердження про цінність нації як найвищої форми суспільної єдності та її первинності в державотворчому процесі. Для одних націоналізм $є$ явищем позитивним, яке асоціюється з патріотизмом, в інших - викликає негативні відчуття, пов'язані 3 радикальними формами цієї політичної течії - національним екстремізмом, шовінізмом, а то й нацизмом. Контроверсійність оцінок націоналізму в наукових колах, а також перманентна затребуваність цього френомена в політичній практиці черговий раз актуалізують дослідження в цьому напрямі.

Академічними дослідниками націоналізму $\epsilon$ провідні європейські мислителі XIX-XX ст.: Кон Ганс [20], Джон А. Армстронг [14], Альтер Петер [1], Грінорелд Лія [15], Сміт Ентоні [11]. Дослідженням націоналізму також займалися такі відомі зарубіжні автори, як Ернст Гелнер [16], Карлтон Гейз [17] і Йоган-Готфрід Гердер [18]. Серед українських науковців, які досить успішно підійшли до дослідження окремих аспектів проблем націоналізму, варто згадати Ярослава Грицака [5], Георгія Касья- нова [7], Олега Багана [2], Олександра Сича [13], Олександра Зайцева [6].

Мета та завдання. Проте всіма пропонованими авторами недостатньо представленим $€$ комплексний погляд на історію становлення, типологію, складники поняття й погляд на націоналізм у різні історичні епохи. Метою дослідження є вироблення узагальненого погляду на націоналізм на основі аналізу праць ідеологів і дослідників цього феномена.

Методи дослідження. У статті використано такі наукові методи дослідження: метод історизму, порівняльний та аналітичний методи, структурносистемний аналіз.

Результати. Головна проблема в дослідженні націоналізму полягає в тому, що він позбавлений власної окремої історії, а вивчення історії становлення - це найкращий спосіб для неупередженого та об'єктивного погляду на цей феномен, адже націоналізм розвивався в контексті історії різноманітних країн 3 різним суспільно-політичним устроєм. Як комплекс ідей націоналізм, мандруючи континентами, адаптується до відповідної території, проявляючи властивості хамелеона, тобто набуває барв навколишнього середовища. Варто зазначити, що ця так звана мандрівка континентами збагачує націоналізм не так теоретично, 
як риторично. Тобто за допомогою націоналістичної риторики як фрорми самовираження місцева еліта намагається донести масам свій політичний орієнтир. На практиці можна побачити, як націоналізм в Африці, пов'язаний із соціалістичними ідеями, зовсім відмінний від націоналізму в сучасній Європі, пов'язаного з релігійними чи державотворчими проблемами. Звідси можна простежити той фракт, що німецькі та індійські націоналісти одні й ті самі терміни тлумачать зовсім інакше [10, с. 154].

Націоналізм за своєю сутністю є складним і водночас багатогранним явищем, яке може мати ознаки як демократичні, так й авторитарні, може бути спрямованим у майбутнє чи орієнтованим у минуле.

Порівняно з поняттям «нація» термін «націоналізм» $€$ відносно новим. Першим слово «націоналізм» застосував німецький фрілософ, основоположник культурного націоналізму Йоганн Голторрід Гердер у 1774 році в одному зі своїх творів і фрранцузький церковник-контрреволюціонер абат Огюстен де Барюель у 1798 році майже в тому значенні, що й німецький фрілософр [4, с. 9].

Однак, незважаючи на те що сам термін має відносно недавнє походження, у стародавні та середні віки ми можемо чітко відстежувати прояви окремих національних почуттів і націоналістичних рухів. Можна констатувати, що таке почуття було притаманне античним грекам, на відміну від варварів. У середні віки чіткі прояви націоналізму бачимо у Столітній війні, яку розв'язали між собою англійці та французи. Але загального й масового характеру націоналізм сягнув у новітню добу. Початком утвердження націоналізму можна вважати революції, які охопили в XVII ст. Англію, а пізніше у XVIII ст. Францію, наслідком яких стало усунення королівської влади та проголошення нації як об'єднання вільних громадян, які є джерелом державної суверенності й влади.

Націоналізм, на думку окремих дослідників цього френомена, є політичним напрямом, який впливав на європейську та світову історію протягом останніх двох століть значно більшою мірою, ніж ідеї свободи й парламентської демократії чи ідеї комунізму [1, с. 84].

У XIX-XX ст. під натиском націоналізму впали та розсипалися на велику кількість малих держав такі історично сорормовані монархії, як Османська імперія й Габсбурзька монархія. Протягом цілого XX ст. завдяки проявам націоналістичних стремлінь розпалися на окремі держави Чехословаччина, Югославія й, зрештою, Радянський Союз. Як бачимо, під впливом націоналізму у XX ст. повністю змінилася політична карта Європи й світу загалом. На політичній арені виникли нові незалежні національні держави, які стали самостійними суб'єктами міжнародного права та світової політики.

Однак варто зазначити, що в міжвоєнний період і під час Другої світової війни націоналізм став синонімом нетерпимості, нелюдяності та насильства. Політика геноциду, яку здійснювали націонал-соціалісти, є щодо цього найжахливішим прикладом. Під гаслами націоналізму вели війни та чинили страхітливі злочини.

3 одного боку, під гаслами націоналізму відбувалося захоплення нових територій і знищення людей, з іншого - 3 ним пов'язували національне визволення та встановлення вільного й справедливого ладу.

Як зазначає німецький історик і дослідник націоналізму Петер Альтер, націоналізм засвідчував і засвідчує, що він може бути складником як імперіалізму, так й антиімперіалізму та приховує в собі крайні протилежності й суперечності. Він може означати як звільнення, так і гноблення, а отже, може містити в собі як позитивні можливості, так і потенційні загрози [1, с. 85].

Для націоналізму нація - найвища цінність, єдина обов'язкова інстанція, що надає йому сенсу й виправдовує його. Інтереси нації стають головним джерелом політичного мислення та чину. Нації $€$ тими невід'ємними та основоположними цеглинами, з яких складається суспільна будова людства.

Німецький історик і дослідник націоналізму Фрідріх Майнеке запропонував поділ націй на культурні та політичні (державницькі). Культурну націю творять ії найважливіші та найвагоміші цінності, які її водночас і об'єднують в одне ціле: спільна мова, спільна культура та спільна релігія. Культурна нація може існувати й без державних інститутів. Тому культурні націоналісти розглядають державу як щось випадкове, бо сутність нації полягає в її унікальності, як історичній, так і культурній і географрічній. Як зазначає австралійський учений і дослідник націоналізму Джон Гатчінсон: «На відміну від політичного націоналіста, культурний націоналіст уважає, що нація - це не тільки згода й закони, а й почуття, закорінені в природі та історії» [3, с. 499]. Метою культурних націоналістів є передусім моральне відродження історичних спільнот або, іншими словами, відтворення самобутньої національної цивілізації. Прикладом таких націй є поляки після втрати своєї державності, німці та італійці до політичного об'єднання в другій половині XIX ст.

Головною запорукою створення політичних націй є спільне політичне співіснування в одному державному об'єднанні громадян і їхнє прагнення до самовиявлення та самореалізації. Неможливо визначити точний період заснування політичної нації, але можна констатувати, що населення держави стало політичною нацією, а держава - національною, якщо тривалий час є природне внутрішнє й зовнішнє почуття політичної спільності. Тому політична нація характеризується високим рівнем політичної свідомості громадян, які $€$ рівними перед законом, незалежно від їхнього соціального статусу, етнічного походження та віросповідання. 
Основною метою політичних націоналістів $€$ представницька національна держава, яка б гарантувала своїм громадянам однакові громадянські права. Вони прагнуть організувати суспільне життя на раціонально-правових засадах, створюючи централізовані установи для мобілізації різних суспільних груп, щоб спрямовувати їх супроти наявної політичної системи та задля досягнення унітарної цілісності. Прикладом політичних націй є Франція, США, Велика Британія.

Культурна нація може бути водночас і політичною. Тому іноді важко визначити, що їі сильніше згуртовує - політичний чи культурний чинник. Ідеться про те, що всередині справжньої політичної нації можуть жити, як свідчить приклад Швейцарії, представники різних культурних націй. І, навпаки, культурна нація може містити в собі кілька політичних націй. Тобто відчуття політичної спільності серед населення держави $€$ визначальним чинником самобутності нації, але водночас вона може залишатися частиною більшої, ширшої, що виходить за межі певної території, культурної нації, навіть часто не усвідомлюючи цього [9, с. 265].

Отож, нація, як ми можемо бачити, - це часом непростий, але необхідний симбіоз культурних (етнічних) і громадянських (політичних) елементів, який сорормований на бюрократичних і культурницьких підвалинах. У цьому, власне, й полягає успіх будь-якої нації на сучасному етапі життя. Таке групування дає змогу розглядати народ одночасно як громадян, так й етнічних членів, одні 3 яких керують державними органами, а інші згуртовують енергію та потенціал народу. Культура і громадянство підсилюють одне одного й повністю реалізовують потенціал нації, якщо зберігається рівновага в цьому симбіозі. Тобто, коли майже немає розколу між громадянською й етнічною складниками, це поєднання практично бездоганне. Але коли громадянський або етнічний елемент підноситься над іншим, тоді цей симбіоз розхитується і розривається на шматки, підриваючи єдність і могутність нації. Як результат, громадянство й етнічність можуть бути доведені до конфронтації та конорлікту, що сталося, власне, у Франції в кінці XIX ст. під час справи Дрейфусса [11, с. 141]. Як зазначає німецький фрілософр, основоположник культурного націоналізму Йоган Гердер: «Зло й занепад охоплюють націю тільки внаслідок внутрішніх суперечностей і конфрліктів - чи внаслідок крайнощів раціоналізму, який запроваджує пасивну залежність від держави, чи внаслідок окостенілості традиції, яку спостерігаємо в Середні віки» [18, с. 172].

Отже, націоналізм, про який іде мова, є націоналізмом на основі етносу або на основі тієї політичної нації, яка історично склалася зі значної кількості етносів і яка усвідомлює себе неподільною, де міжетнічні чи расові межі є згладженими, неяскравими та неглибокими.
Один із фрундаторів наукових досліджень націоналізму Карлтон Дж. Гейз стверджує, що націоналізм у процесі свого фрормування пройшов кілька етапів розвитку. Від XVIII ст. відстежується фрормування гуманістичного націоналізму, який представлений націоналістичними доктринами Ж.-Ж. Руссо, Й.-Г. Гердера. Дещо пізніше починає утверджуватися якобінський націоналізм із його революційними методами досягнення мети. Інтереси європейської консервативної аристократії представляв так званий традиційний націоналізм, який відкидав революційні зміни, а опирався на стійкі традиції та цінності нації. Наступником традиційного націоналізму став ліберальний націоналізм, який сфрормований у працях Дж. Мадзіні в Італії, Д. Бентам в Англії та Ф. Гізо у Франції. Фундаментальною цінністю цього різновиду націоналізму була держава. Головна сутність полягала в тому, що кожна нація має право на власну державу, а державна влада повинна узгоджуватися з правами та свободами особистості. На зміну ліберальному націоналізму приходить його повна протилежність - інтегральний (наступальний) націоналізм. Тут засадничою цінністю є етнічна нація, яка є стрижнем та основним об'єднавчим чинником суспільного й державного життя. Цей різновид націоналізму категорично відкидав гуманістичні цінності, а власна нація для інтегрального націоналіста - найкраща, найвища та найцінніша [17].

Основоположник історичних досліджень націоналізму, єврейський фрілософ Ганс Кон сфрормував теорію про два типи націоналізму, які склалися історично, - «західний» (раціональний) і «східний» (культурницький, містичний) націоналізм.

Західний тип націоналізму ґрунтувався на принципах індивідуалізму, обстоював ідеї рівності, братерства, принципи плюралістичного й відкритого суспільства. Економічно та політично його підтримувала впливова буржуазія (середній клас). Цей тип націоналізму розглядав націю як фрорум «суспільного договору». Західний націоналізм, на переконання Г. Кона, фрормувався на хвилі піднесення націоналізму, був суто політичною подією, його появі передувало створення майбутньої національної держави або, як у випадку Сполучених Штатів, творення цих двох процесів відбувалося одночасно. Як зазначив Г. Кон, західний націоналізм сформувався в межах наявної політичної реальності без надто емоційного погляду в минуле. Націоналізм західного типу був витвором нації, яка фрормувала свій світогляд на основі політичних і соціальних чинників.

Інший тип націоналізму - східний - ґрунтувався на статусі та авторитеті його членів, якихоб'єднували традиційні родинні зв'язки. Як стверджує Ганс Кон, «східний» націоналізм відкидає раціоналізм і вимагає повного підпорядкування інтересів особистості інтересам нації й держави, абсолютизує принцип колективізму. Цей тип націоналізму виявляється передусім у сорері культури, створюється штучно, 
на основі місрів про минуле або мрій про майбутнє а отже, в ньому відсутня будь-яка політична реальність. Спочатку цей націоналізм існував у фрормі мрій і сподівань учених, поетів та аристократів, які апелювали до «славного минулого» та специфічних «культурних атрибутів» - мови, фрольклору, історичних міфрів тощо [8, с. 481].

Здійснюючи порівняльний аналіз «західного» і «східного» націоналізму в рамках своєї типології, Г. Кон підкреслює ту обставину, що другий тип націоналізму, який народився поза межами Західної Європи, внаслідок нижчого рівня суспільнополітичного розвитку перебував під безпосереднім або опосередкованим впливом першого, що тривалий час залишався й учителем, і взірцем. Але ця залежність від Заходу уражала гордість освічених класів «сходу», i, зрештою, вони стають в опозицію цьому «чужому» західному впливу з його ліберальним і раціональним світоглядом, починають розвивати власний націоналізм.

На поглиблення розбіжностей у різних концепціях нації та націоналізму суттєво вплинули епохи Відродження й Рефрормації.

Як зазначає Г. Кон: «На Заході Відродження та Ресрормація створили нове суспільство, в якому середній клас і світська освіта отримали значну перевагу, а універсальне та імперське римське поняття середньовічного світу було відкинуто не лише на практиці, а й у теорії. Однак у Центральній і Східній Європі ця середньовічна ідея світової імперії залишилася і, спираючись на дослідження давнини, здобула навіть нову силу - нереальну, але захоплюючу силу примарного світу» [8, с. 482].

Тому події, які відбувалися під впливом Відродження та Реформації, не тільки не зблизили ці два типи націоналізму, а й ще більше посилили старі розбіжності між Західною та Східною цивілізаціями.

Східному націоналізму під впливом зовнішніх обставин постійно бракувало впевненості. Як зазначає український дослідник націоналізму Георгій Касьянов: «Будучи залежним від впливів ззовні й водночас намагаючись протистояти їм, цей новий націоналізм, який не мав коріння в політичній і соціальній реальності, відчуває невпевненість; його комплекс меншовартості часто обертається надзвичайною самовпевненістю й самозахопленням; в уяві націоналістів Німеччини, Росії або Індії їхній власний націоналізм був чимось незмірно глибшим, багатшим на проблеми і потенціальні можливості, аніж націоналізм Заходу» [7].

Автором ще одної концепції націоналізму є один із найвідоміших західних дослідників націоналізму, професор соціології Лондонської школи економіки Ентоні Сміт. Він виокремлює територіальний та етнічний націоналізм. Водночас Е. Сміт виділяє в кожному із цих націоналізмів рух перед здобуттям незалежності й рух після здобуття незалежності. Відповідно до цього, етнічний націоналізм поділяється на сепаратистський і діаспорний націоналізм, головним завданням яких $€$ відколотись від більшої політичної одиниці й заснувати на її місці нову політичну «етнічну націю», та іредентистський і «пан»-націоналізм, які в основному намагаються поширитись, приєднуючи до себе етнічних «родичів» поза межами кордонів «етнічної нації», або сорормувати більшу «етнонаціональну» державу через об'єднання в союз культурно й етнічно близьких етнонаціональних держав. У свою чергу, територіальний націоналізм ділиться на антиколоніальні, прагненням яких $є$ на місці колишньої колоніальної території створити нову державну націю, прогнавши перед тим завойовників, та інтеграційні, які інтегрують та об'єднують навколо себе в політичну спільноту часто етнічно строкате населення, витворюючи нову «територіальну націю» [12, с. 497]

Існує ще багато класифрікаційних і типологізаційних теорій націоналізму, але розглянути всі в нас немає змоги, та й, зрештою, немає сенсу. Адже жодна з них не може претендувати на універсальність, а лише $є$ аналітичною базою для вивчення різновидів націоналізму.

Багато науковців виходять із того, що націоналізм - це рух, метою якого є пошук тісного зв'язку між державою та нацією, без якого націоналізм втрачає своє суспільне й політичне значення. Без такого поєднання націоналізм міг би зацікавити хіба що фрольклористів [11, с. 157]. Націоналізм вимагає національної держави, бо саме цей процес (творення національної держави) зміцнює націоналізм. У такий спосіб існує безперервна взаємозалежність і взаємодія між націоналізмом і національною державою. Очевидним є той фракт, що саме розвиток i поширення націоналізму сприяли виникненню держав. Багато дослідників поєднують поняття «національна держава» нерозривно 3 поняттями «нація» та «націоналізм». Е. Ґелнер визначав націоналізм як політичний принцип, згідно з яким «політична та національна одиниці мають збігатися» [4, с. 29]. Через принцип національного самовизначення, якого націоналісти послідовно дотримувалися, фрормувався такий важливий для модерної історії френомен, як «національна держава».

За визначенням Е. Ґелнера, націоналізм - це політичний принцип, за яким етнічні, культурні кордони мають збігатися з політичними, тобто державними. Іншими словами, націоналізм вимагає укладення «законного шлюбу» між національною культурою й національною державою [16].

Націоналізм твердить, що нація та держава існують одне для одного, більше того, одне без одного не можуть існувати, а відсутність одного з них трагедія для іншого. Тому націоналізм має на меті змусити державу працювати на благо та інтереси нації й бути їх послідовним виразником. А нація, у свою чергу, має стати ґрунтом і критерієм держави. Отже, держава сама по собі є лише знаряддям для реалізації волі нації, і її (держави) пози- 
ція повинна визначатися волею людей, означених як громадянська або етнічна нація. Водночас національна держава утверджується та міцніє завдяки домінантному етносу, якому вона допомогла сорормуватися й набрати форми моноліту.

Як зазначає Ентоні Сміт: «Держава, на створення якої націлюється націоналізм, - це культурно означене та вкрите культурним гримом політичне утворення, воно здобуває свій сенс існування, як і свій характер, із історичної культури домінантного етносу або - рідше - 3 історичних культур більше ніж одного етносу» [11, с. 159].

Національні держави залишатимуться основними суб'єктами світової політики, доки існуватиме взаємна підтримка між нацією та державою, де останні захищають і зберігають національну ідентичність, а нації створюють усі передумови для міцності й належного розвитку національних держав.

Отже, підсумовуючи, можемо констатувати, що термін «націоналізм» $€$ доволі новим явищем порівняно 3 нацією. Хоча часом зародженням націоналізму вважають XVII-XVIII ст., перші його прояви знаходимо в далеку античну епоху. В окремі періоди свого історичного розвитку націоналізм у різних країнах і на різних територіях набував різного значення. Дуже часто націоналізм ставав маніпулятором у руках політиків, які використовували його для досягнення своїх політичних цілей.

Водночас необхідно усвідомлювати, що націоналізм має багато різних форм і течій, які за конкретних історичних обставин дають розуміння того, що означає в тому чи іншому випадку цей френомен. Існує багато класифікаційних і типологізаційних теорій націоналізму (частина з них представлена в дослідженні, зокрема Фрідріха Майнеке, Карлтона Дж. Гейза, Ентоні Сміта), але найбільш достовірною, на думку автора статті, є типологія націоналізму єврейського дослідника Ганса Кона, який поділяє націоналізм у процесі його історичного розвитку на східний і західний. Проте автор статті в жодному разі не наполягає на універсальності цієї типології, як і будь-якої іншої.

Висновки. Узагальнюючи, вважаємо за потрібне зазначити, що саме поняття «націоналізм» не містить у собі оцінних категорій. Воно лише констатує той фракт, що на політичній арені визрів новий суб'єкт політичного процесу, який усвідомив свої прагнення й інтереси та окреслив конкретні цілі. Націоналізм стверджує, що людство поділене на самодостатні нації, кожна з яких має право на творення власної держави, у якій вона, нація, є найвищою суспільною цінністю. Зміцнення національної держави, носієм суверенітету в якій $€$ нація, $€$ основною умовою самоствердження та самореалізації останньої.

Суспільна затребуваність ідеології націоналізму в сучасних реаліях світового політичного процесу залишає цей напрям дослідження доволі перспективним.

\section{ЛІТЕРАТУРА:}

1. Альтер П. Націоналізм: проблема визначення. Націоналізм: Антологія / упорядники О. Проценко, В. Лісовий. Київ: Смолоскип, 2010. С. 85-88.

2. Баган О. Націоналізм і націоналістичний рух. Дніпропетровськ: Видавнича фрірма «Відродження», 1994. 192 c.

3. Гатчінсон Дж. Культурний і політичний націоналізм. Націоналізм: Антологія / упорядники О. Проценко, В. Лісовий. Київ: Смолоскип, 2010. С. 499-506.

4. Гелнер Е. Нації та націоналізм. Націоналізм / пер. 3 анг. Київ: Таксон, 2003. 300 с.

5. Грицак Я. Страсті за націоналізмом. Стара історія на новий лад. Київ: Критика, 2011. 176 с.

6. Зайцев О. Український інтеґральний націоналізм (1920-ті -1930-ті роки). Нариси інтелектуальної історії. Київ: Критика, 2013.

7. Касьянов Г. Теорії нації та націоналізму: монограсрія. Київ: Либідь, 1999. 352 с.

8. Кон Г. Західний і східний націоналізм. Націоналізм: Антологія / упорядники О. Проценко, В. Лісовий. Київ: Смолоскип, 2010. С. 479-482.

9. Майнеке Ф. Загальний погляд на націю, національну державу і космополітизм. Націоналізм: Антологія / упорядники О. Проценко, В. Лісовий. Київ: Смолоскип, 2010. С. 264-272.

10. Майноуг К. Анатомія націоналізму. Націоналізм: Антологія / упорядники О. Проценко, В. Лісовий. Київ: Смолоскип, 2010. С. 119-155.

11. Сміт Е. Нації та націоналізм у глобальну епоху / пер. з англ. М. Климчука і Т. Цимбала. Київ: Ніка-Центр, 2013. 278 с.

12. Сміт Е. Територіальні та етнічні націоналізми. Націоналізм: Антологія / упорядники О. Проценко, В. Лісовий. Київ: Смолоскип, 2010. С. 495-498.

13. Сич О. Український націоналізм: традиція і модерн: (вибр. ст., лекції, інтерв'ю, рецензії). ІваноФранківськ: Місто НВ, 2011. 222 с.

14. Armstrong J. Nations before Nationalism. Chapel Hill: University of North Carolina Press, 1982. 410 p.

15. Greenfeld L. Nationalism: Five Roads to Modernity. Cambridge, MA: Harvard University Press, 1992. $581 \mathrm{p}$.

16. Hellner E. Nations and Nationalism. Cornell University Press, 1983. 150 p.

17. Hayes C.J. The Historical Evolution of the Modern Nationalism. New-Jork, 1948. 187 p.

18. Herder J.G. Reflections on the philosophy of the history of mankind / Ed. F. Manuel. Chicago, 1968. 401 p. 19. Hutchinson J., Smith A. Nationalism. Oxford: Oxford University Press, 1994. 378 p.

20. Kohn H. Nationalism: its meaning and history. Revised ed. Princeton-Toronto-New York-London: D. Van Nostrahd Company, Inc, 1965. 191 p.

\section{REFERENCES:}

1. Alter P. (2010) Natsionalizm: problema vyznachennya [Nationalism: problem definition]. Natsionalizm: Antologiya / Uporyadnyky O. Protsenko, V. Lisovyy. Kyiv: Smoloskyp [in Ukrainian]. S. 85-88.

2. Bahan O. (1994) Natsionalism i natsionalistychnyy ruh [Nationalism and nationalist movement]. Drohobych: Vydavnycha firma «Vidrodzhennya» [in Ukrainian]. 192 s. 
3. Hatchinson G. (2010) Kulturnyy i politychnyy natsionalizm [Cultural and political nationalism]. Natsionalizm: Antologiya / Uporyadnyky O. Protsenko, V. Lisovyy. Kyiv: Smoloskyp [in Ukrainian]. S. 499-506.

4. Helner E. (2003) Natsiyi ta natsionalizm [Nations and Nationalism]/ Natsionalizm: Per. Z angl. Kyiv: Takson [in Ukrainian]. $300 \mathrm{~s}$.

5. Hrytsak Y. (2011) Strasti za natsionalizmom. Stara istoriya na novyy lad [Passion for nationalism. Old story in a new way]. Kyiv: Krytyka [in Ukrainian]. 176 s.

6. Zaytsev O. (2013) Ukrains'kyy integral'nyy natsionalizm (1920-1930 roky). Narysy intelektual'noyi istoriyi [Ukrainian integral nationalism (1920-1930 years). Essays on intellectual history] Kyiv: Krytyka [in Ukrainian].

7. Kas'yanov H. (1999) Teoriyi natsiyi ta natsionalismu: Monografiya [The theory of nation and nationalism: a monograph] Kyiv: Lybid' [in Ukrainian]. $352 \mathrm{~s}$.

8. Kon H. (2010) Zahidnyy i shidnyy nastionalizm [Western and eastern nationalism]. Natsionalizm: Antologiya / Uporyadnyky O. Protsenko, V. Lisovyy. Kyiv.: Smoloskyp [in Ukrainian]. S. 479-482.

9. Mayneke F. (2010) Zagal'nyy pohlyad na natsiyu, natsional'nu derzhavu i kosmopolityzm [A general view of a nation, national state and cosmopolitanism] // Natsionalizm: Antologiya / Uporyadnyky O. Protsenko, V. Lisovyy. Kyiv: Smoloskyp [in Ukrainian]. S. 264-272.

10. Maynouh K. (2010) Anatomiya natsionalizmu [Anatomy of nationalism]. Natsionalizm: Antologiya / Uporyadnyky O. Protsenko, V. Lisovyy. Kyiv: Smoloskyp [in Ukrainian]. S. 119-155.

11. Smit E. (2013) Natsiyi ta natsionalizm u global'nu epokhu [Nations and nationalism in a global era].
Per. z angl. M. Klymchuka I T. Tsymbala. Kyiv: NikaTsentr [in Ukrainian]. $278 \mathrm{~s}$.

12. Smit E. (2010) Terytorial'ni ta etnichni natsionalizmy [Territorial and ethnic nationalisms]. Natsionalizm: Antologiya / Uporyadnyky O. Protsenko, V. Lisovyy. Kyiv: Smoloskyp [in Ukrainian]. S. 495-498.

13. Sych O. (2011) Ukrains'kyy natsionalizm: tradytsiya i modern (vubr. s, lektsiyi, intervyu, retsenziyi ) [Ukrainian nationalism: tradition and modernity: (selected articles, lectures, interviews, reviews)] Ivano-Frankivs'k: Misto HB [in Ukrainian]. $222 \mathrm{~s}$.

14. Armstronh J. (1982) Natsiyi do natsionalizmu [Nations before Nationalism] Chapel Hill: University of North Carolina Press [in English]. 410 p.

15. Hrinfild L. (1992) Natsionalism: p'yat' shlyakhiv do modernosty [Nationalism: Five Roads to Modernity]. Cambridge, MA: Harvard University Press [in English]. $581 \mathrm{p}$.

16. Helner E. (1983) Natsiyi ta Ntsionalizm [Nations and Nationalism]. Cornell University Press [in English]. $150 \mathrm{p}$.

17. Hayes K. (1948) Istorychna evolyutsiya modernoho natsionalizmu [The Historical Evolution of the Modern Nationalism]. New-Jork [in English]. 187 p.

18. Herder H. (1968) Ideyi do filosofiyi istoriyi lyudstva [Reflections on the philosophy of the history of mankind] / Ed. F. Manuel. Chicago [in English]. 401 p.

19. Hutchinson J., Smit A. (1994) Natsionalizm [Nationalism]. Oxford: Oxford University Press [in English]. $378 \mathrm{p}$.

20. Kon H. (1965) Natsionalizm: yoho znachennya ta istoriya [Nationalism: its meaning and history]. Revised ed. Princeton-Toronto-New York-London: D. Van Nostrahd Company, Inc [in English]. 191 p.

\section{The phenomenon of nationalism: the history of the formation, typology and the essential characteristics}

\section{Starodub Taras Petrovych}

Postgraduate Student at the Department of Political Science and International Relations

National University "Lviv Polytechnic" Stepan Bandera Str., 12, Lviv, Ukraine
The purpose of this study is to develop own view of nationalism based on the analysis of the work of ideologists and researchers of this phenomenon.

The study used the following research methods: the method of historicism, comparative and analytical methods, structural and system analysis.

It is carried out a comprehensive analysis of the history of nationalism, the typology, the composite of this concept, it is clarified the view on nationalism in different historical epochs. The article shows that nationalism, at its core, is a complex and difficult phenomenon and at the same time, multi-faceted, which can have the characteristics of both democratic and authoritarian, can be directed or focused into the future to the past. It is analyzed a variety of classification and typologizing theories of nationalism but significant is a typology of nationalism written by a jewish researcher, to the opinion of the author of the article, a jewish scholar, philosopher Hans Kohn, who shared the nationalism in the process of its historical development, on the East and West.

It is clarified that nationalism, that the nation is a supreme value, the only binding authority that makes sense of and justifies it. It is established that the main principle of nationalism is the establishment and strengthening of national state sovereignty in which there is a nation. Many scholars believe that nationalism is a movement whose goal is the search for close ties between the state and the nation, without which nationalism loses its social and political significance. Without such a combination of nationalism could interest only folklorists. Nationalism requires a nation-state, because this process (of creating a nation-state) strengthens nationalism. Thus, there is a continuous interdependence and interaction between nationalism and the nation state. Obvious is the fact that the development and spread of nationalism contributed to the emergence of States. Many researchers combine the concept of "nation state" is closely connected with concepts of "nation" and "nationalism". Nationalism argues that the nation and the state exist for each other, and moreover, one without the other cannot exist, and the absence of one entails the tragedy for another.

Key words: nationalism, nation, nation-state, historiography of nationalism, types of nationalism, theories of nationalism. 